\title{
International Mathematical Congress Medals
}

$\mathrm{E}$ VERY four years there is held an international gathering of mathematicians, known as the International Congress of Mathematicians. At the next meeting, to be held in Oslo in 1936, two gold medals will be awarded to mathematicians selected for their outstanding contributions to mathematics by an international committee appointed for the purpose. The foundation of these medals is due to the efforts of the late Dr. J. C. Fields, research professor of mathematics at the University of Toronto. Dr. Fields was responsible for assembling the Mathematical Congress in Toronto in 1924-the

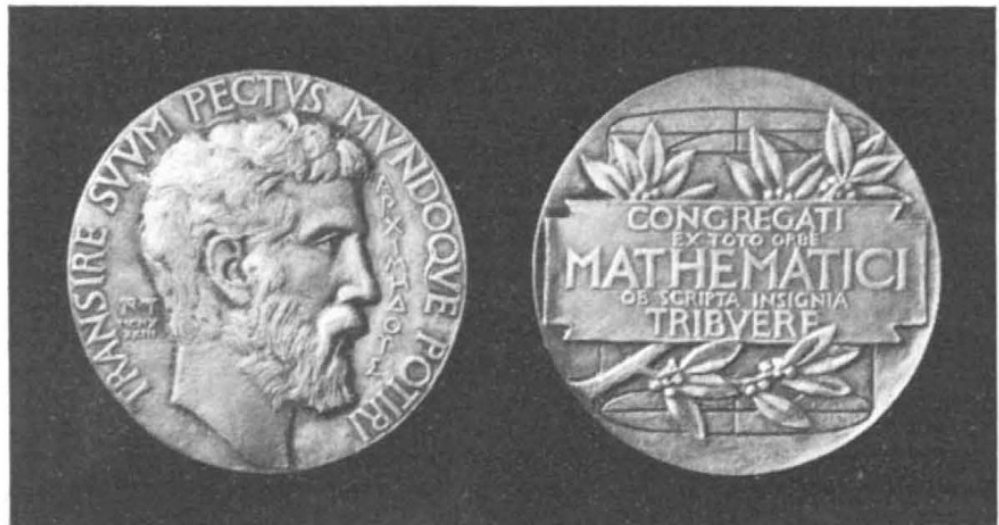

FrG. 1. Medal of the International Mathematical Congress. his work (Fig. 1).

Fields, it was his particular wish that in design and award they should be truly international in character, and should not be associated with any country or person. The task of designing a suitable medal was entrusted to the distinguished Canadian sculptor, Dr. R. Tait McKenzie, R.C.A., who has now completed

The medal is two and a half inches in diameter. The obverse shows the head of Archimedes facing right. As there are no authentic portraits of this perhaps greatest of all mathematicians, recourse was had to the fine collection of more than thirty pictures collected by Prof. David Eugene Smith, and placed by him in Columbia University. They show the idea of as many artists, ancient and modern, of what Archimedes may have appeared to be. They naturally vary greatly, so thesculptor followed his own impression from reading his life and works. $\mathrm{He}$ shows the sage as a man of mature age, vigorous, with curly hair and beard, straight Greek nose and prominent brow. In the field is the word "Archimedous" in Greek capitals, and the artist's monogram, "RTM" and "MCMXXXIII".

The inscription surrounding it is : "Transire suum pectus mundoque potiri", which may be freely translated: "To transcend one's human

only meeting which has been held outside Europe-and was president of the Congress and the editor of its Proceedings, which constituted two large volumes, published by the University of Toronto Press. With funds remaining after the completion of the work, Dr. Fields suggested the foundation of these medals, as a Canadian contribution to the cause of international scientific co-operation, which he always had much at heart. Unfortunately, Dr. Fields did not live to see the realisation of his scheme, as he died in August 1932, a month before the meeting of the Congress in Zurich, which gave international approval to the foundation of the medals. The medals will be awarded at each International Congress of Mathematicians in future.

In spite of the fact that the medals are of Canadian origin and are due to the personal efforts of Dr. limitations and master the universe." This appropriate quotation from the Roman poet Manilius was supplied by Prof. Norwood of the University of Toronto.

The reverse has a label bearing the inscription :

"Congregati ex toto orbe mathematici ob scripta insignia tribuere", which may be freely translated :

"Mathematicians gathered together from the whole world honour noteworthy contributions to knowledge."

Behind the label is a laurel branch, and cut in the background can be made out the diagram of a sphere contained in a cylinder. The determination of the relation of these two was one of the outstanding achievements of Archimedes, and this diagram was engraved on his tomb. The name of the recipient will be cut on the edge of the medal and will not interfere with the design.

\section{Narcosis and Mental Function}

$\mathrm{N}$ a paper read before Section $\mathrm{J}$ (Psychology) of the 1 British Association at Leicester, Dr. J. H. Quastel, director of the Research Laboratory, Cardiff City Mental Hospital, gave an account of recent experiments with narcotics. The evidence points to narcotics acting primarily by producing a state equivalent to anoxæmia at the particular parts of the nervous system where they are absorbed. Also the psychological effects of narcosis and of oxygen want are very similar to each other.

The narcotic drugs tested have the common property of inhibiting, at low concentrations, the oxidation in the nervous system of substances important in carbohydrate metabolism, such as glucose and lactic acid, for which the effects are practically specific. If certain other substances are investigated which are freely oxidised by the brain, this inhibition of oxidation does not take place. The main effect of the narcotic appears to be at the nervous cells, where it interferes with the activation of the lactic acid molecule, a process which is necessary before its oxidation can take place. The narcotic and the lactic acid compete for the cell catalysts involved in the activation process.

The following picture may be given of the mechanism of narcosis. Absorption of the narcotic takes place from the blood stream at a nervous centre. There it competes with lactic acid for the 